\title{
Grazia Rusticali, Da Enid a Guinevere. Le storie arturiane di Tennyson
}

G. Matteo Roccati

\section{(2) OpenEdition}

\section{Journals}

Édition électronique

URL : http://journals.openedition.org/studifrancesi/34251

DOI : 10.4000/studifrancesi.34251

ISSN : 2427-5856

Éditeur

Rosenberg \& Sellier

\section{Édition imprimée}

Date de publication : 1 novembre 2005

Pagination : 388

ISSN : 0039-2944

\section{Référence électronique}

G. Matteo Roccati, « Grazia Rusticali, Da Enid a Guinevere. Le storie arturiane di Tennyson », Studi

Francesi [En ligne], 146 (XLIX | II) | 2005, mis en ligne le 30 novembre 2015, consulté le 18 avril 2021.

URL : http://journals.openedition.org/studifrancesi/34251 ; DOI : https://doi.org/10.4000/

studifrancesi.34251 


\title{
Grazia Rusticali, Da Enid a Guinevere. Le storie arturiane di Tennyson
}

\author{
G. Matteo Roccati
}

\section{RÉFÉRENCE}

GRAZIA RUSTICALI, Da Enid a Guinevere. Le storie arturiane di Tennyson, Roma, Carocci

(«Biblioteca medievale. Saggi», 15), 2004, pp. 240.

1 Lorsque Alfred Tennyson compose ses Idylls of the King (1859-1888), il connaît les Mabinogion (lus dans la traduction anglaise de Lady Charlotte Guest, parue à partir de 1838), sans doute indirectement les romans de Chrétien de Troyes et quelques autres textes, la compilation de Thomas Malory (trois éditions en 1816-1817). Le volume examine quelques unes des figures féminines des Idylls (Enid, Elaine, Vivien, Ettarre, Lynette, Guinevere) en montrant comment A.T. réélabore la matière médiévale en fonction des valeurs de la société victorienne. 